\title{
184. STUDIES IN THE BIOCHEMISTRY OF MICRO-ORGANISMS
}

\section{SYNTHESIS OF CYNODONTIN ( $\mathrm{I}: 4: 5: 8$-TETRA- HYDROXY-2-METHYLANTHRAQUINONE) \\ A METABOLIC PRODUCT OF SPECIES OF HELMINTHOSPORIU்M}

\author{
- BY WINSTON KENNAY ANSLOW AND HAROLD RAISTRICK \\ From the Division of Biochemistry, London School of Hygiene \\ and Tropical Medicine, University of London
}

\section{(Received 1 November 1940)}

Cynodontin was first isolated by chloroform extraction of the dried mycelium of laboratory cultures of the fungi Helminthosporium cynodontis Marignoni and $H$. euchlaenae Zimmermann by Raistrick et al. [1933, 1] and by the same workers from $H$. avenae Eidam [1934]. It was shown to be almost certainly 1:4:5:8tetrahydroxy-2-methylanthraquinone (III). since it was obtained in vitro [Raistrick et al. 1933, 1], by the oxidation with manganese dioxide and concentrated $\mathrm{H}_{2} \mathrm{SO}_{4}$ of helminthosporin, a metabolic product of $\mathrm{H}$. gramineum Rabenhorst [Charles et al. 1933] and helminthosporin was shown by synthesis to be 4:5:8-trihydroxy-2-methylanthraquinone [Raistrick et al. 1933, 2].

We have now confirmed by synthesis the suggested molecular structure for cynodontin. 4-Methyl-3:6-dimethoxyphthalic anhydride (I) [Anslow \& Raistrick, 1940] was condensed with 1:4-dimethoxybenzene (II) by treatment with anhydrous $\mathrm{AlCl}_{3}$ in $\mathrm{CS}_{2}$ solution. Simultaneous demethylation and ring closure of the resulting acid was effected by heating with conc. $\mathrm{H}_{2} \mathrm{SO}_{4}$ at $150^{\circ}$. The resulting polyhydroxyanthraquinone which must, from its method of synthesis, be 1:4:5:8-tetrahydroxy-2-methylanthraquinone (III) was identical in all its properties with cynodontin isolated from different species of Helminthosporium.

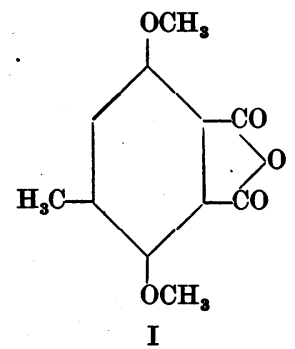

I

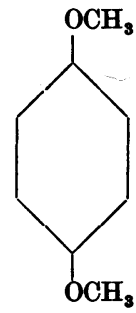

II

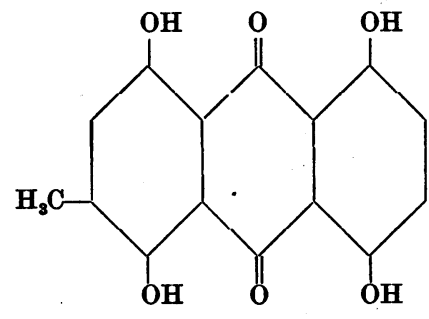

III

\section{EXPERIMENTAL}

(a) Condensation of 4-methyl-3:6-dimethoxyphthalic anhydride with 1:4dimethoxybenzene. Freshly powdered anhydrous aluminium chloride $(4 \cdot 4 \mathrm{~g}$.) was added at short intervals in five approximately equal amounts to a mixture of 4-methyl-3:6-dimethoxyphthalic - anhydride (2 g.) and 1:4-dimethoxybenzene $(4 \mathrm{~g}$.) in dry carbon disulphide $(50 \mathrm{ml}$.). The mixture, which quickly became 
yellow and then orange in colour, was boiled under reflux for $8 \mathrm{hr}$. After standing overnight the supernatant $\mathrm{CS}_{2}$ was decanted from the dark brown semi-solid mass which was decomposed with $2 N \mathrm{HCl}(75 \mathrm{ml}$.), the mixture being cooled during the process. The residue remaining after evaporation of the $\mathrm{CS}_{2}$ solution was added and the excess of 1:4-dimethoxybenzene was removed by distillation in steam. The oily residue quickly solidified on cooling and was extracted with ether (1 1.). The ether solution was dried over anhydrous $\mathrm{MgSO}_{4}$ and on removal of the solvent the crude benzoyl acid was obtained as a brownish yellow oil which later solidified (2.44 g.).

(b) Demethylation and ring closure of the substituted benzoyl acid. The crude acid (2.44 g.), without further purification, was heated with conc. $\mathrm{H}_{2} \mathrm{SO}_{4}(20 \mathrm{ml}$.) in an oil bath at $150^{\circ}$ for $35 \mathrm{~min}$. The $\mathrm{H}_{2} \mathrm{SO}_{4}$ solution, which was initially greenishblue in colour with a fine green fluorescence, became deep blue in colour with an intense red fluorescence after $15 \mathrm{~min}$. heating. The anthraquinone, which was separated by pouring the cooled reaction mixture into iced water $(600 \mathrm{ml}$.), was coagulated by heating on a boiling water bath for $30 \mathrm{~min}$. and was separated by filtration as a chocolate brown amorphous powder $(1.40 \mathrm{~g}$.). This crude material was extracted with chloroform (Soxhlet) and there separated from the eosincoloured extract brown leaflets with a bronze lustre (0.76 g.; M.P. $\left.255-260^{\circ}\right)$. Evaporation of the chloroform mother liquors and sublimation of the residue in a high vaouum gave a further $\mathbf{0} \cdot 36 \mathrm{~g}$. of crude anthraquinone.

(c) 1:4:5:8-Tetraacetoxy-2-methylanthraquinone (cynodontin tetraacetate). The anthraquinone $\left(0.76\right.$ g.; M.P. $\left.255-260^{\circ}\right)$ separating from chloroform was purified by conversion into the acetate. It was dissolved in a mixture of pyridine $(25 \mathrm{ml}$.) and acetic anhydride $\left(5 \mathrm{ml}\right.$.) and held at $37^{\circ}$ for 2 days. The reaction mixture was filtered and the filtrate was poured into ice-water $(400 \mathrm{ml}$.). The acetate (0.87 g.) which separated was crystallized twice from glacial acetic acid (norite). Pale yellow prisms $\left(0.44\right.$ g.), M.P. $224-226^{\circ}$ alone or in admixture with the tetraacetate prepared from natural cynodontin. (Found: $\mathrm{C}, 60 \cdot 57,60 \cdot 42 ; \mathrm{H}, 3.99$, $4 \cdot 12 \% . \mathrm{C}_{23} \mathrm{H}_{18} \mathrm{O}_{10}$ requires $\mathrm{C}, 60 \cdot 77 ; \mathrm{H}, 4.00 \%$.) A further $0 \cdot 11 \mathrm{~g}$. of pure acetate was obtained by acetylating in the same way the $0.36 \mathrm{~g}$. of crude anthraquinone obtained from the chloroform mother liquors.

(d) 1:4:5:8-Tetrahydroxy-2-methylanthraquinone (cynodontin). Pure 1:4:5:8tetraacetoxy-2-methylanthraquinone $(0 \cdot 4 \mathrm{~g}$.) was hydrolysed by heating under reflux on a boiling water bath with $2 \mathrm{~N}$ aqueous $\mathrm{NaOH}(30 \mathrm{ml}$.) in an atmosphere of nitrogen for $2 \mathrm{hr}$. The tetraacetate quickly dissolved to give an intensely blue-violet solution. The anthraquinone was precipitated with $2 N \mathrm{HCl}(40 \mathrm{ml}$.), coagulated by heating on a boiling water bath for $\mathbf{3 0}$ min., filtered, washed and dried. This material $(0.25 \mathrm{~g}$.) was crystallized from pyridine $(30 \mathrm{ml}$. with norite) and 1:4:5:8-tetrahydroxy-2-methylanthraquinone was thus obtained in brown leaflets with a fine bronze lustre (0.19 g.; M.P. $\left.260-261^{\circ}\right)$, alone or in admixture with cynodontin from Helminthosporium cynodontis. (Found: C, 62.94, 62.88; $\mathrm{H}, 3.67,3.65 \% . \mathrm{C}_{15} \mathrm{H}_{10} \mathrm{O}_{6}$ requires $\mathrm{C}, 62.91 ; \mathrm{H}, 3.52 \%$.) The synthetic and natural specimens are both insoluble in cold dilute aqueous $\mathrm{Na}_{2} \mathrm{CO}_{3}$. Both dissolve in cold aqueous $2 \mathrm{~N} \mathrm{KOH}$ to give deep blue-violet solutions and solutions of both in cold conc. $\mathrm{H}_{2} \mathrm{SO}_{4}$ are intense pure blue in colour with a fine red fluorescence.

\section{SUMMARY}

Cynodontin (1:4:5:8-tetrahydroxy-2-methylanthraquinone), a metabolic product of different species of Helminthosporium, has been synthesized. 4-Methyl3:6-dimethoxyphthalic anhydride was condensed with 1:4-dimethoxybenzene 
and the resulting acid was simultaneously demethylated and converted into 1:4:5:8-tetrahydroxy-2-methylanthraquinone by heating with conc. $\mathrm{H}_{2} \mathrm{SO}_{4}$. The synthetic and natural products were shown to be identical.

\section{REFERENCES}

Anslow \& Raistrick (1940). Biochem. J. 34, 1124.

Charles, Raistrick, Robinson \& Todd (1933). Biochem. J. 27, 499.

Raistrick, Robinson \& Todd $(1933,1)$. Biochem. J. 27, 1170.

- - $(1933,2)$. J. chem. Soc. p. 488.

$\longrightarrow-(1934)$. Biochem. J. 28, 559. 